\title{
TAXONOMIC SURVEY OF THE POLIA (POLIA) NEBULOSA SPECIES COMPLEX (NOCTUIDAE, NOCTUINAE, HADENINI), WITH THE DESCRIPTION OF TWO NEW SUBSPECIES
}

\author{
Zoltán VARGA ${ }^{1}$, Gábor Ronkay ${ }^{2}$ and László Ronkay ${ }^{3}$ \\ ${ }^{1}$ Department of Evolutionary Zoology and Human Biology, University of Debrecen \\ H-4010 Debrecen, Hungary; E-mail: varga.zoltan@science.unideb.hu \\ ${ }^{2}$ Heterocera Press Ltd., H-1137 Budapest, Szent István krt. 4, Hungary \\ E-mail: gaborronkay@gmail.com \\ ${ }^{3}$ Department of Zoology, Hungarian Natural History Museum \\ H-1088 Budapest, Baross u. 13, Hungary \\ E-mail: ronkay.laszlo@nhmus.hu; https://orcid.org/0000-0001-9153-4902
}

\begin{abstract}
The morphologically most distinct Holarctic species-group of Polia is reviewed. It consists of three Palearctic and four Nearctic species. Biogeographical and phylogenetic connections of the species-group are discussed. Lectotype of $P$. nebulosa askolda is designated. Taxonomic subdivision of $P$. lama is presented, with the description of two new subspecies: P. lama leucobliterata (Uzbekistan: W Hissar Mts) and P. lama anthracosparsa (Pakistan: Karakoram Mts). Genital characters of Eurasiatic taxa are described and illustrated.
\end{abstract}

Key words: Palearctic, Holarctic, sister species, species-groups, genitalia, phyletic lineages.

\section{INTRODUCTION}

The genus Polia Ochsenheimer, 1816 (and the subgenus Polia) obviously had an Eurasiatic origin since all closely related genera sharing the plesiomorphic, nearly symmetrical genital capsule (VARGA \& RonKay 2013) are SouthEast Palearctic (Haderonia Staudinger, 1896, Tricheurois Hampson, 1905) or Central Asiatic (Ctenoceratoda Varga, 1992). The great majority of Polia taxa are also East Palearctic, including the members of the recently separated and described subgenera Atropolia, Metallopolia and Protopolia (VArga et al. 2017, 2018). According to nucleotide sequences of the CO1 gene, the subgenus Polia s. str. is subdivided into two main phyletic lines (ZAHIRI et al. 2014). However, considering the characters of genitalia of both sexes, the phyletic connections seem to be more complicated. There are two, not closely related species which show striking autapomorphies in the corresponding lock-and-key structures of the vesica-bursa complex. The widely distributed Central Asiatic-Siberian Polia subcontigua Eversmann, 1852 (= P. altaica Lederer, 1853), with helicoid vesica and reduction of fasciculate cornuti, represents some convergence to the Lacanobia-related monotypic Spiramater McCabe, 1980. This species has 
nearly symmetrical short saccular processes, without the typical bipartition of fasciculate brushes on the left-sided process (VARGA \& Ronkay 2013). The other "outlier", P. hepatica Clerck, 1759, is one of the well-known Euro-Siberian Polia species. Its saccular processes are also relatively short and nearly symmetrical, with simple brushes (rather similarly to the probably closely related P. griseifusa Draudt, 1950), while the curiously coiling vesica seems to correspond with the unusual distal-lateral positioning of the appendix bursae. According to the barcode evidence, this species is representing one of the basal splits within Polia s. str. (Huemer pers. comm.). Oppositely, P. serratilinea Treitschke, 1825 belongs to the mostly derived species with adaptations to the arid or rupicolous habitats. Morphologically (strongly asymmetrical saccular processes, bipartition of fasciculate brushes, weak ampulla, apically elongate juxta) it can be associated to that species-group of Polia which is mostly represented in the mountains of southern Siberia.

This latter group of species (purpurissata-group sensu McCABE 1980) is mostly distributed in the arctic and boreal zones. The strictly localised species, P. atrax Draudt, 1950 occurs in the high mountains of West China (Yunnan, Sichuan) but the diversity core area seem to be found in the southern Siberian high mountains with three East Palearctic montane ( $P$. malchani Draudt, 1934, P. tiefi Püngeler, 1914, $P$. vespertilio Draudt, 1934) and several cooccurring widely distributed species. One single species, $P$. richardsoni Curtis, 1835 has a circum-boreal distribution, its sibling species $P$. lamuta Herz, 1903 is Euro-Siberian arctic-alpine (Heydemann 1944), another species has a wide but disjunct boreo-montane distribution ( $P$. vesperugo Eversmann, 1856) with a North American sister species (P. propodea McCabe, 1980). Finally, the polytypic Polia bombycina Hufnagel, 1766 has a wide Trans-Palearctic range with a sister sibling species-pair in North America (P. purpurissata Grote, 1864 and $P$. nugatis Smith, 1898, see also McCABE 1980, ZaHiRi et al. 2014).

The other main phyletic line of the genus, the nebulosa species-group has a wide temperate Palearctic ( $P$. nebulosa Hufnagel, 1766, P. lama Staudinger, 1896, P. goliath Oberthür, 1880) but also Nearctic distribution (see below). The three Palaearctic species are externally forming two groups as $P$. goliath is strikingly different from the often confusingly similar P. nebulosa and P. lama though both related species have conspicuous intraspecific differentiation, too. P. nebulosa shows a peculiar mixture of plesiomorphic and autapomorphic characters. It has a well-developed basal abdominal brush organ (a plesiomorphic feature throughout Hadenini) which is reduced in P. lama to the pedicel of the organ. Moreover, P. nebulosa has strongly sclerotised, acute ampulla and a strongly sclerotised crest on the left side saccular process. Both species show remarkable geographical variation which seems to be more clinal in P. nebulosa within the largest part of the Palearctic region, with the exception of the Pacific, 
Far Eastern province, while P. lama is subdivided into allopatric subspecies at the western and southern edges of the range (see below).

McCABE (1980) already hypothesized that four North American Polia species are closely related with the Eurasiatic $P$. nebulosa, and this Nearctic group of species is possibly a descendent of the "nebulosa"-lineage. It is differentiated to the P. piniae Buckett and Bauer, 1967 - P. discalis Grote, 1877 speciespair near to the Pacific coast, while P. nimbosa (Guenée, 1852) and P. imbrifera (Guenée, 1852) seem to be more distant and also widely distributed in the boreo-temperate zone. According to the strongly asymmetrical tufts on the saccular processes and the extremely elongated neck of cucullus (males), and the strongly sclerotised, medially constricted ductus bursae with trapezoidal distal part and broad antrum (females), they form a derived monophyletic group which is also characterised by the trend of loss of the basal abdominal brush organ in the more derived $P$. nimbosa $-P$. imbrifera species-pair.

\section{Original descriptions of the taxa of the Polia nebulosa species group}

Mamestra nebulosa var. lama Staudinger, 1896, Deutsche Entomologische Zeitschrift, Gesellschaft Iris zu Dresden 9: 241. Type-locality: Uliassutai [Mongolia, Khangay Mts].

Mamestra enodata Bang-Haas, 1912, Deutsche Entomologische Zeitschrift, Gesellschaft Iris zu Dresden 26: 145, pl. 6, fig. 10. Type locality: "Karagai-tau", [NW China, Xinjiang, E Tien Shan].

Polia enodata expallidata Varga, 1974, Annales historico-naturales Musei nationalis hungarici 66: 306, fig. 10. Type-locality: Mongolia, Bayan Ölgiy aimak, Khovd river.

Dichonia goliath Oberthür, 1880, Études d'Entomologie 5: 68, pl. 6, fig. 7.Type-locality: Askold [Island], [Russia].

Mamestra discalis Grote, 1877, In: Uhler, Bulletin of the U.S. Geological E Geographical Survey Territories 3: 797. Type locality: Clear Creek Canyon (U.S., Colorado).

Polia piniae Buckett et Bauer, 1967, Journal for Research of Lepidoptera 5: 221. Type locality: Johnsville, Plumas Co., California (Davis).

Aplecta imbrifera Guenée, 1852, Histoire Naturelle des Insectes (Lépidoptères) 6: 76. Type locality: "New York".

Aplecta nimbosa Guenée, 1852, Histoire Naturelle des Insectes (Lépidoptères) 6: 77. Type locality: "Amerique Septentrionale".

\section{LECTOTYPE DESIGNATION \\ OF POLIA (POLIA) NEBULOSA ASKOLDA (OBERTHÜR, 1880)} (Fig. 5)

Aplecta nebulosa var. askolda Oberthür, 1880, Études d'Entomologie 5: 79. Type-locality: [Russia] Askold [Island].

Lectotype: male, "Aplecta nebulosa var. askolda" [Russia] Askold [Island], in coll. BMNH. Lectoparatypes: 3 males and 1 female, in coll. BMNH (Figs 6-8). 
Taxonomic differentiation of $P$. lama - The species P. lama was originally described by Staudinger as a "varietas" of $P$. nebulosa (see: original description) and it has long been confused with the Central Asiatic populations of $P$. nebulosa, despite certain recognisable external differences (see the detailed characterisation below). Some years later another population of P. lama was considered as a distinct species and described from the Tien Shan Mts (see: original description). The specific identity of the Mongolian $P$. lama with $P$. enodata was recognised by VARGA (1974) describing it as a subspecies of $P$. enodata (Polia enodata expallidata Varga, 1974 (see: original description) since, unfortunately, the type-specimen of $P$. lama was not studied at this time. This mistake was only corrected in our recent paper (VARGA et al. 2018). In summary, the nominotypical $P$. lama lama is represented by the Mongolian population and P. lama enodata is its most widely distributed subspecies.

The nominate Polia lama lama is nearly concolorous grey with some clay-ochreous shine and fine, occasionally faint marking which is often suffused by dispersed blackish-brown scales. The forewing is less pointed and the outer margins of wings are less crenulated than in the other subspecies. The hindwings are basally whitish and the discal lunule is faint. The dorsal tufts on the first abdominal segments are only slightly darker than the colouration of the abdomen. These characters show, however, some variation as the specimens from North-western Mongolia (Mongol Altai Mts) seem to be somewhat darker than the specimens from the type-locality (Khangai Mts). There are some minor differences also in the male genital capsule: the "neck" of the cucullus is on average slightly shorter and the lower edge of the "head" of the cucullus is less acute than in the subspecies enodata. It occurs in western and Central Mongolia, inhabiting mostly the lower and medium altitudes, appearing often in riverine willow-poplar gallery forests.

Polia lama enodata is the best known and most widely distributed subspecies of P. lama which occurs in the Tien Shan and Pamir-Alai mountain systems. The colouration of the thorax and forewings is pure (or only slightly ochreous) grey with finely or densely dispersed blackish-brown scales and with rather regular dark grey marking. Forewings are elongate and apically acute, outer margins strongly crenulate. Hindwings are whitish grey with more or less contrasting discal and subterminal bands. Dorsal tufts on the first abdominal segments are dark brownish grey or blackish. The "neck" of the cucullus is relatively long and slender; the lower edge of the relatively small "head" is acute. It is widely distributed in several Central Asiatic mountainous regions, from the western Tien Shan (Chatkal range) across the Central Tien Shan range (Kirghisia, Tadjikistan) to North-East Afghanistan (Prov. Badakhshan) and often frequently occurs at medium and high altitudes in a broad variety of habitats; known also from numerous "classical" localities (e.g. Kirghisia: 'Fort Naryn', China, Xinjiang area: "Aksu"). 
Two other subspecies occur at the south-western and southern margins of the range of the latter subspecies. The first seems to be highly isolated in the western part of the Hissar range in Uzbekistan while the other is widely distributed in the mountains of the former Kashmir.

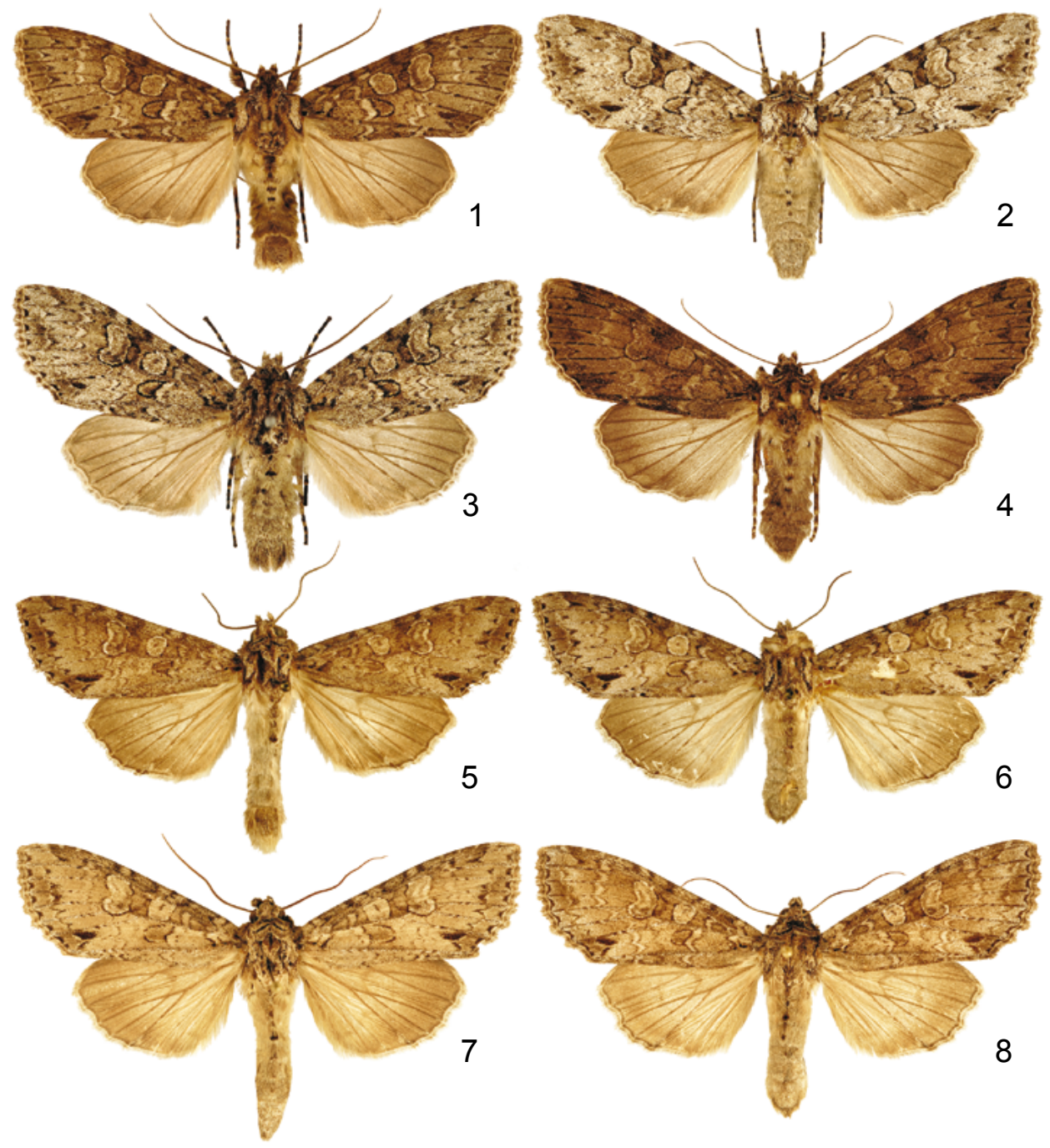

Figs 1-8. Polia nebulosa imagoes. $1-4=P$. n. nebulosa (Hufnagel, 1766): $1=$ male (wingspan = $53 \mathrm{~mm}$ ), Germany (wingspan $=57 \mathrm{~mm}), 2=$ female, Germany, $3=$ male $($ wingspan $=49$ $\mathrm{mm}$ ), Germany, $4=$ female (wingspan $=59 \mathrm{~mm}$ ), Hungary; $5-8=$ P. $n$. askolda (Oberthür, 1880): $5=$ male, lectotype, Russia, Askold Island (wingspan $=51 \mathrm{~mm}), 6=$ female, paralectotype, Russia, Askold Island (wingspan $=58 \mathrm{~mm}$ ), $7=$ male (wingspan $=52 \mathrm{~mm}$ ), Russian Far East, $8=$ female, Russian Far East (wingspan $=58 \mathrm{~mm}$ ) 
Abbreviations - BMHN - The Natural History Museum London (formerly British Museum, Natural History); HNHM - Hungarian Natural History Museum, Budapest; MNB - Museum für Naturkunde, Berlin; NHMW - Naturhistorisches Museum, Vienna; SMNK - Staatliches Museum für Naturkunde, Karlsruhe; ZSM - Zoologische Staatssammlung, Munich

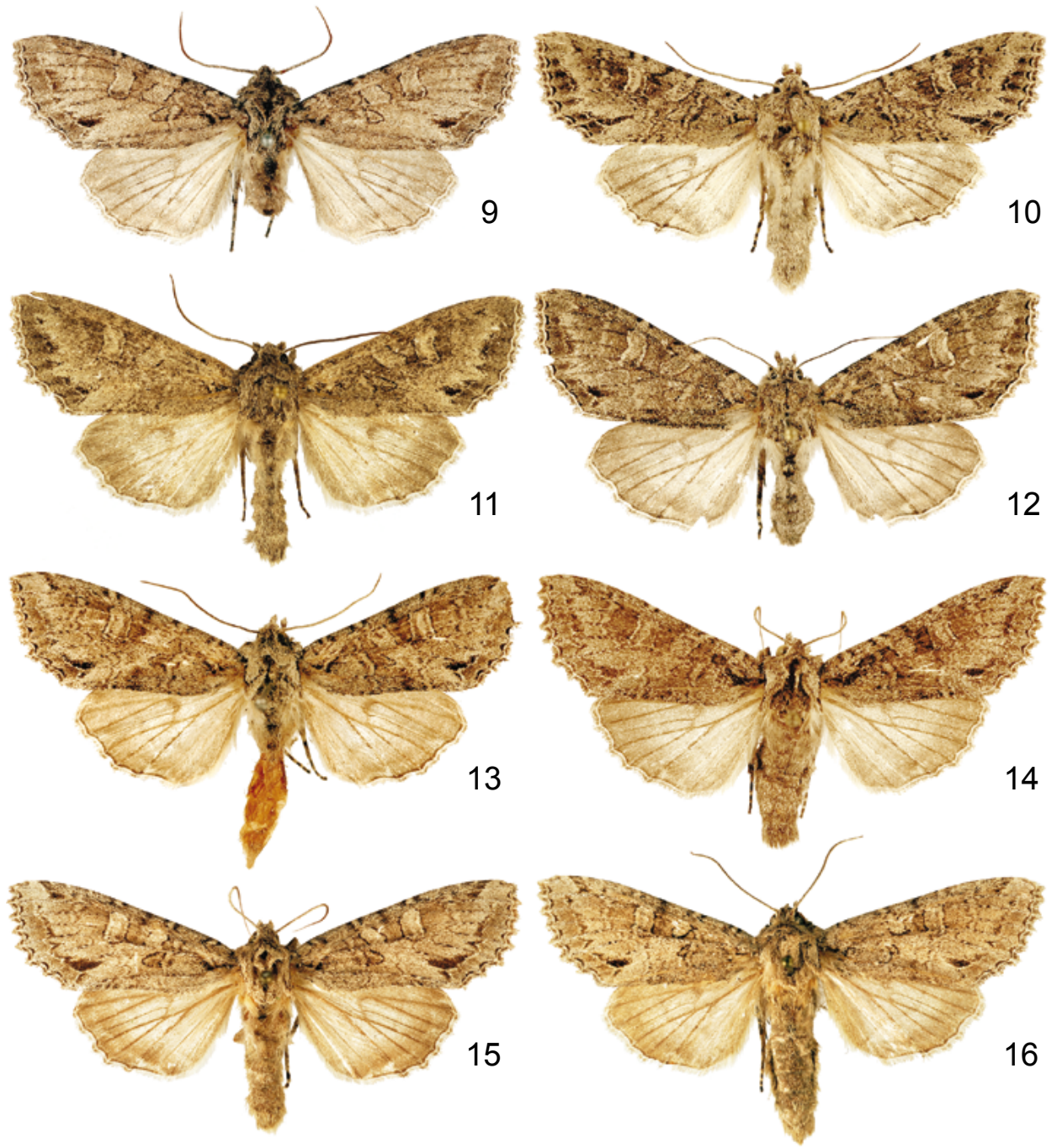

Figs 9-16. Polia lama imagoes. $9-12=$ P. l. lama (Staudinger, 1896), Mongolia: $9=$ male, holotype $($ wingspan $=43 \mathrm{~mm}), 10=$ male $($ wingspan $=44 \mathrm{~mm}), 11=$ male $($ wingspan $=44$ $\mathrm{mm}), 12=$ female $($ wingspan $=47 \mathrm{~mm}) ; 13-16=P$. l. enodata $($ Bang-Haas, 1912$): 13=$ male, lectotype, Kazakhstan, Karagai-Tau (wingspan $=44 \mathrm{~mm}$ ), $14=$ male, Kirghisia, Chatkal $($ wingspan $=43 \mathrm{~mm}), 15=$ female, Kirghisia, Naryn (wingspan $=48 \mathrm{~mm}), 16=$ female, Kirghisia, Naryn (wingspan $=47 \mathrm{~mm}$ ) 


\section{Polia lama leucobliterata ssp. n.}

(Figs 17, 18, 35, 36)

Holotype: male, Uzbekistan, W Hissar Mts, Mt. Maidanak, 2500 m, 38²40N, 66 $53^{\prime} \mathrm{E}$, 25.VI.2007, leg. local collector (coll. G. Ronkay, Budapest).

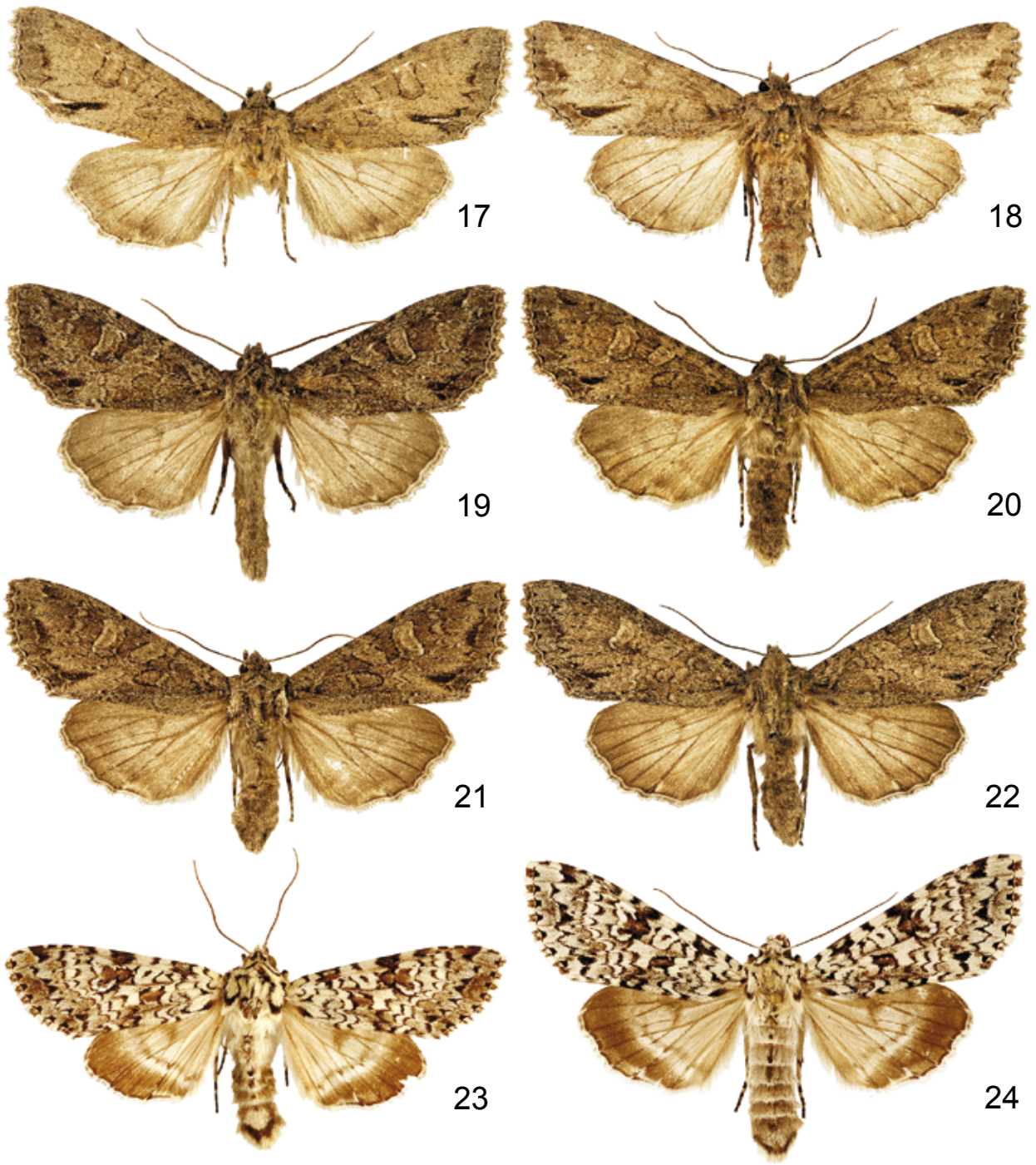

Figs 17-24. 17-18 = Polia lama leucobliterata ssp. n.: 17 = male, holotype, Uzbekistan, Hissar Mts, 18 = female, paratype, Uzbekistan, Hissar Mts; 19-22 = Polia lama anthracosparsa ssp. n.: 19 = male, holotype, Pakistan, Karakoram Mts, 20-21 = female, paratype, Pakistan, Himalaya Mts, 22 = female, paratype, Pakistan, Hindukush Mts; 23-24 = Polia goliath (Oberthür, 1880): 23 = male, holotype, Russia, Askold Island, 24 = female, Russian Far East 
Paratypes: Uzbekistan. 2 males, 3 females, with the same data as the holotype. The paratypes are deposited in coll. P. Gyulai (Miskolc), G. Ronkay (Budapest) and the HNHM (Budapest).

Genitalia slides: RL11992m (male, holotype), VZ9224m (male, paratype), VZ9791m (male, paratype), RL11993f (female, paratype).

Diagnosis. The westernmost population of P. lama in the Hissar Mts strongly differs from the typical subspecies (Figs 9-12) and the ssp. lama enodata (Figs 13-16) by its on average slightly larger size and stronger body, the blurred forewing pattern (with the exception of the conspicuous long arrowhead spot at the tornus), the more whitish hindwing, and by certain slight differences in the male clasping apparatus (Fig. 35), i.e. the shorter "neck" and the triangular, relatively large "head" of the cucullus.

Description. Relatively large moths (wingspan: male $46-50 \mathrm{~mm}$, female $53-55 \mathrm{~mm}$ ) with strong body, elongate forewings with less acute apex, pale ochreous-grey ground colour, blurred maculation and crosslines but with prominent blackish-brown tornal arrowhead streak. Hindwings basally whitish-grey with light ochreous-grey terminal band and ochreous shine. Dorsal tufts on the first abdominal segments less prominent. Sexes similar but the marking of females are somewhat more diluted.

In the male genitalia, the genital capsule (Fig. 35) is strongly asymmetrical, the right saccular process is rather short, slightly recurved terminally, and the left process has two prominent tufts of strong setae. Cucullus relatively large, its "neck" is slightly shorter than in the other subspecies of $P$. lama. Aedeagus moderately sclerotised, slender, vesica with two prominent diverticula medially and a long fascia of cornuti terminally.

In the female genitalia (Fig. 36), antrum broad triangular, ductus bursae relatively slender, appendix bursae dome-shaped, corpus bursae with two larger and one smaller signa.

\section{Polia lama anthracosparsa ssp. n.}

$$
\text { (Figs 19-22, 37-39) }
$$

Holotype: male, Pakistan, Karakoram Mts, Naltar valley, 2800 m, $74^{\circ} 12^{\prime} \mathrm{E}, 36^{\circ} 09^{\prime} \mathrm{N}$, 18.VII. 1998, leg. G. Ronkay \& Z. Varga (coll. G. Ronkay, Budapest).

Paratypes. Pakistan. Karakoram Mts: 9 males from the same locality and data, leg. G. Ronkay \& Z. Varga; 3 males and 1 female from the same locality, 20.VII.1998, leg. leg. G. Ronkay \& Z. Varga; 13 males from the same locality, 16.VII.1994, leg. B. Herczig, Gy. M. László \& G. Ronkay (colls HNHM, P. Gyulai, G. Ronkay and HNHM); 1 male, with the same data, but 3000 m, 7404’ E, 36²14N, 16.VII.1994, leg. B. Herczig, Gy. M. László \& G. Ronkay (coll. P. Gyulai); 21 males and 8 females from the same locality, 30.VI.2000, leg. G. Ronkay \& Z. Varga (colls P. Gyulai, G. Ronkay, Z. Varga); 1 male, 1 female, Naltar valley, 2900 m, 26-27.VI.2014, leg. Benedek \& Babics (coll. P. Gyulai); 1 male, Deintar valley, 3000 m, 28.VI.2014, leg. Benedek \& Babics (coll. P. Gyulai); 1 male, Gilgit, Naltar, 3000-3200 m, 19-23.VII.1982, leg. Eckweiler, coll. Thöny (coll. HNHM). Hindukush Mts: 3 males and 6 females, $5 \mathrm{~km}$ E from Shandur pass, $3500 \mathrm{~m}, 72^{\circ} 32^{\prime} \mathrm{E}, 3610 \mathrm{~N}, 13 . V I I .1994$, leg. B. Herczig, Gy. M. László \& G. Ronkay; 5 males and 8 females from the same locality, 11.VIII.1998, leg. G. Ronkay \& Z. Varga; 5 males, 2 female from the same locality, 24-27.VI.2000, leg. 
G. Ronkay \& Z. Varga (colls G. Ronkay \& Z. Varga). Kashmir, Himalaya Mts, 15 males and 3 females, Deosai plains, Bubin village, $3150 \mathrm{~m}, 74^{\circ} 59^{\prime} \mathrm{E}, 35^{\circ} 12,6^{\prime} \mathrm{N}, 16$.VII.1998, leg. G. Ronkay \& Z. Varga; 3 males from the same locality, 15-19.VIII.1998, leg. G. Ronkay \& Z. Varga; 4 males and 1 female from the same locality, 1-2.VII.2000, leg. G. Ronkay \& Z. Varga

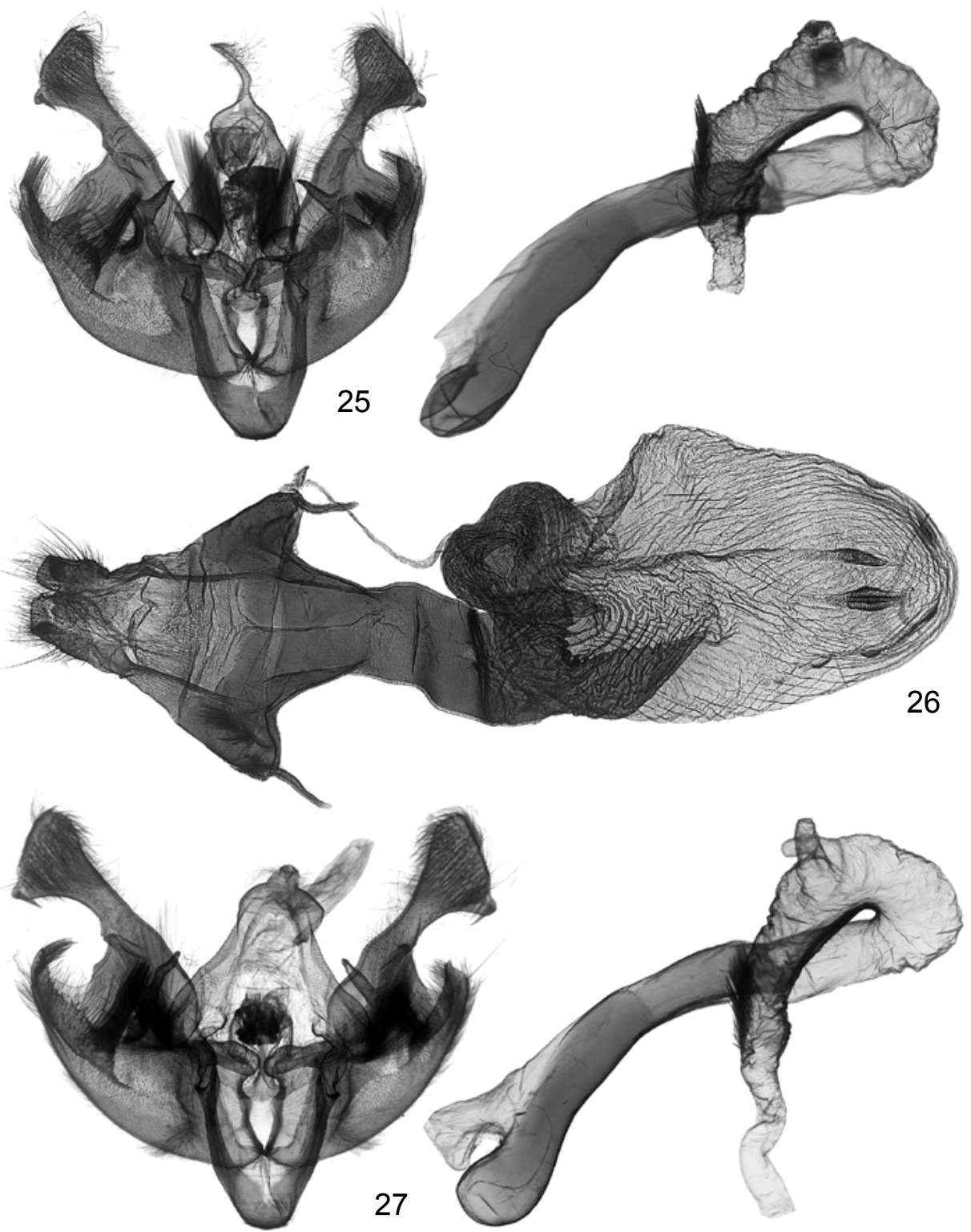

Figs 25-27. Genitalia figures of Polia nebulosa subspecies: 25-26 = P. n. nebulosa (Hufnagel, 1766) 25 = male, Czechia, Moravia, RL12419, 26 = female, Austria, RL12420; $27=P$. n. askolda (Oberthür, 1880) male, Russian Far East, RL12421 
(colls G. Ronkay \& Z. Varga); 7 males, 4 females from the same locality, $3300 \mathrm{~m}, 72^{\circ} 02^{\prime} \mathrm{E}$, $35^{\circ} 13,5^{\prime}$ N, 6.VII.2000, leg. G. Ronkay \& Z. Varga (colls G. Ronkay \& Z. Varga). 1 female, [India], Ladakh, Stagmo, 13000', 9.VII.1912, leg. A. Avinoff (coll. NHM London).
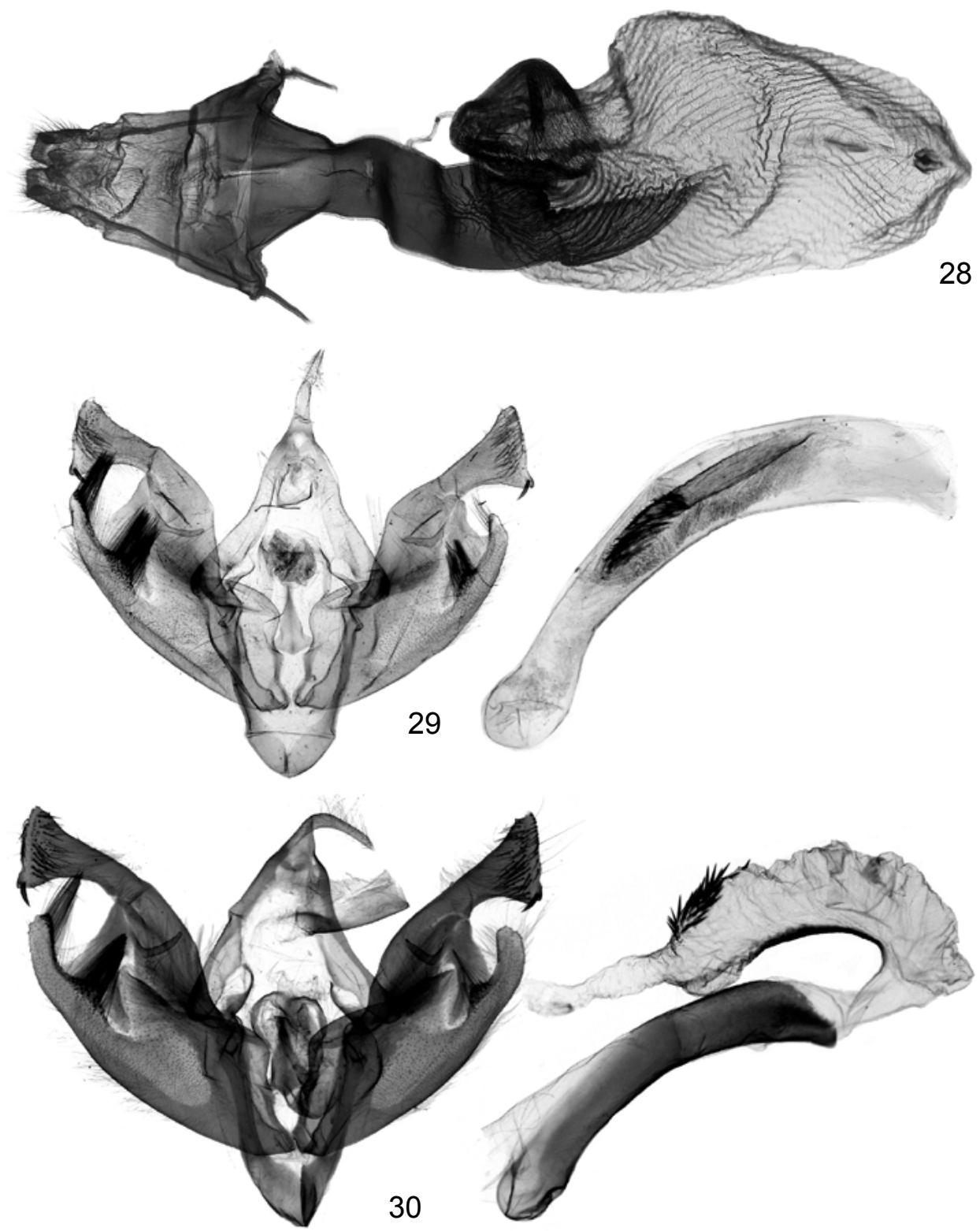

Figs 28-30. Genitalia figures. 28 = Polia nebulosa askolda (Oberthür, 1880): female, Russian Far East, RL12421; 29-30 = Polia lama lama (Staudinger, 1896) male: 29 = holotype, Mongolia, Uliassutai V71/2, 30 = Mongolia, Khangay Mts, RL8752 
Genitalia slides: RL8730m (male, paratype), ТнӧNY299 (male, paratype), VZ8752m (male, paratype), VZ9248m (male, paratype), VZ10019 (male, paratype), VZ10045 (male, paratype), RL12348f (female, paratype), VZ9952 (female, paratype).
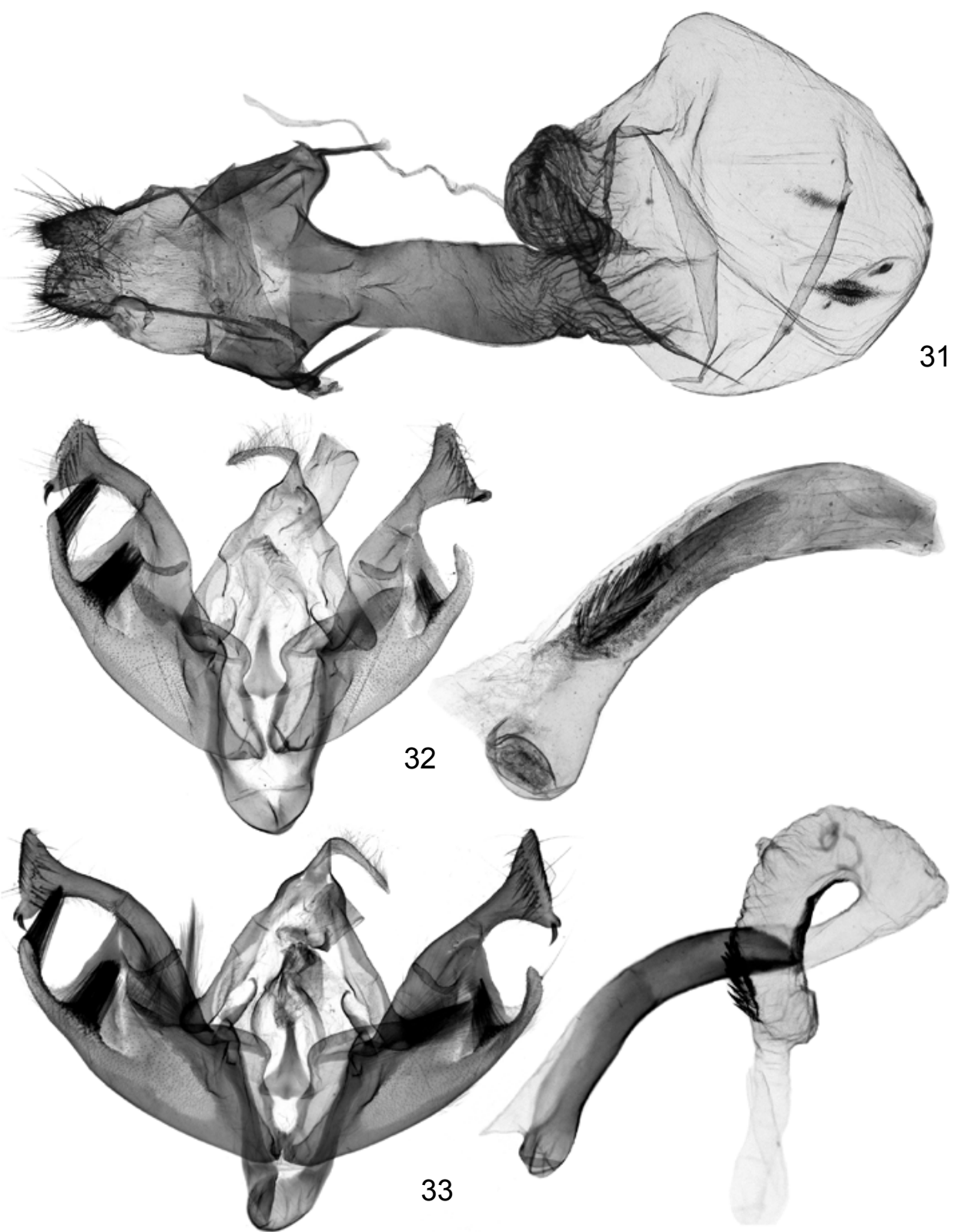

Figs 31-33. Genitalia figures of Polia lama subspecies: $31=$ P. l. lama (Staudinger, 1896) female, Mongolia, RL12349; 32-33 = P. l. enodata (Bang-Haas, 1912) male: 32 = lectotype, Karagai-Tau, Boursin MB356, 33 = Uzbekistan, Chimgan Mts, RL8751 

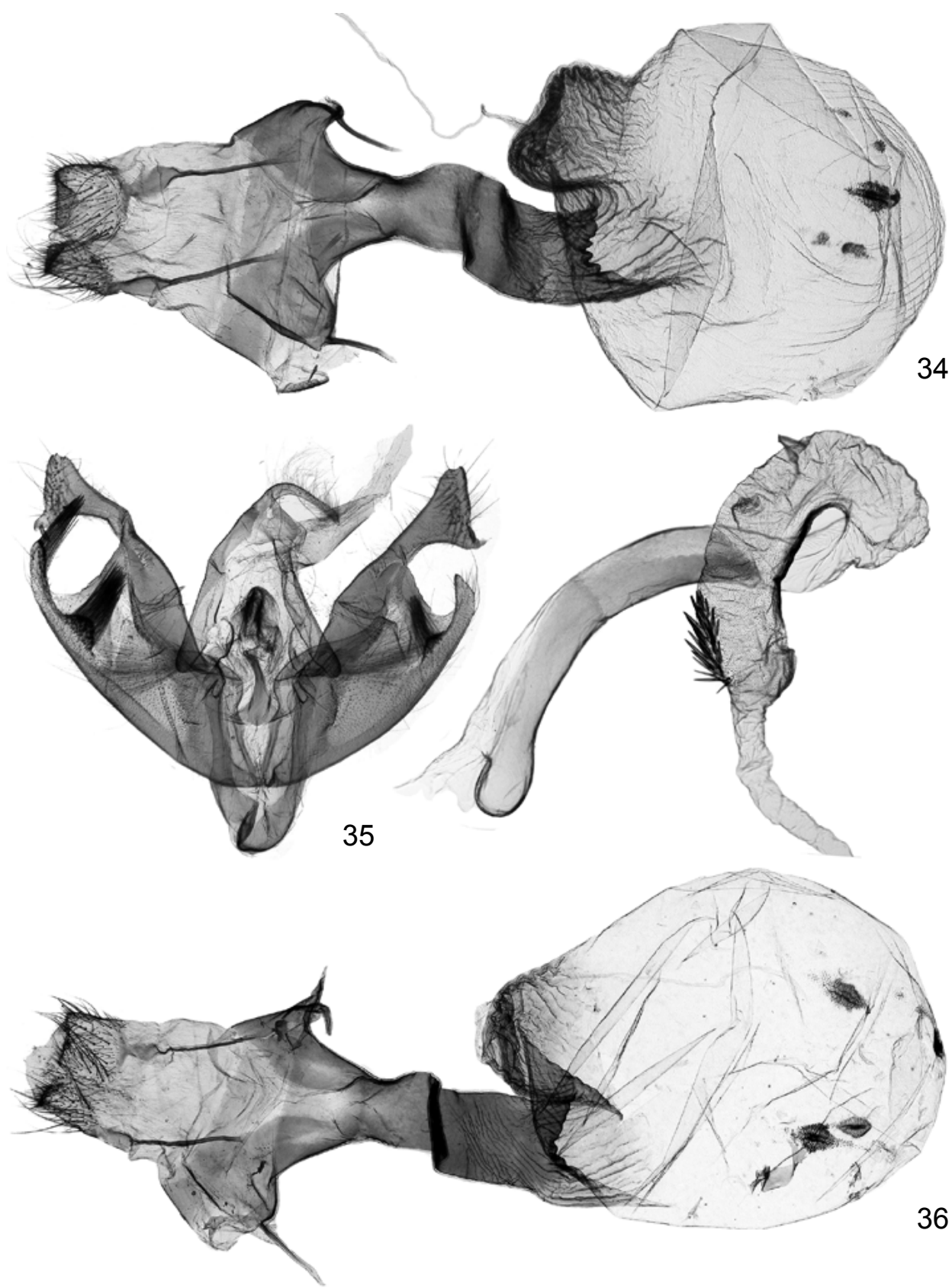

Figs 34-36. Genitalia figures of Polia lama subspecies: $34=$ P. l. enodata (Bang-Haas, 1912) female, Uzbekistan, Naryn, RL12347; 35-36 = P. l. leucobliterata ssp. n.: $35=$ male, holotype, Uzbekistan, Hissar Mts, RL11992, 36 = female, paratype, Uzbekistan, Hissar Mts, RL11993 
Diagnosis. The Pakistani populations from the Hindukush, the Karakoram Mts and the Deosai range in the NW Himalayas differ from the other three races of $P$. lama by their on average larger size (wingspan male $43-48 \mathrm{~mm}$, fe-
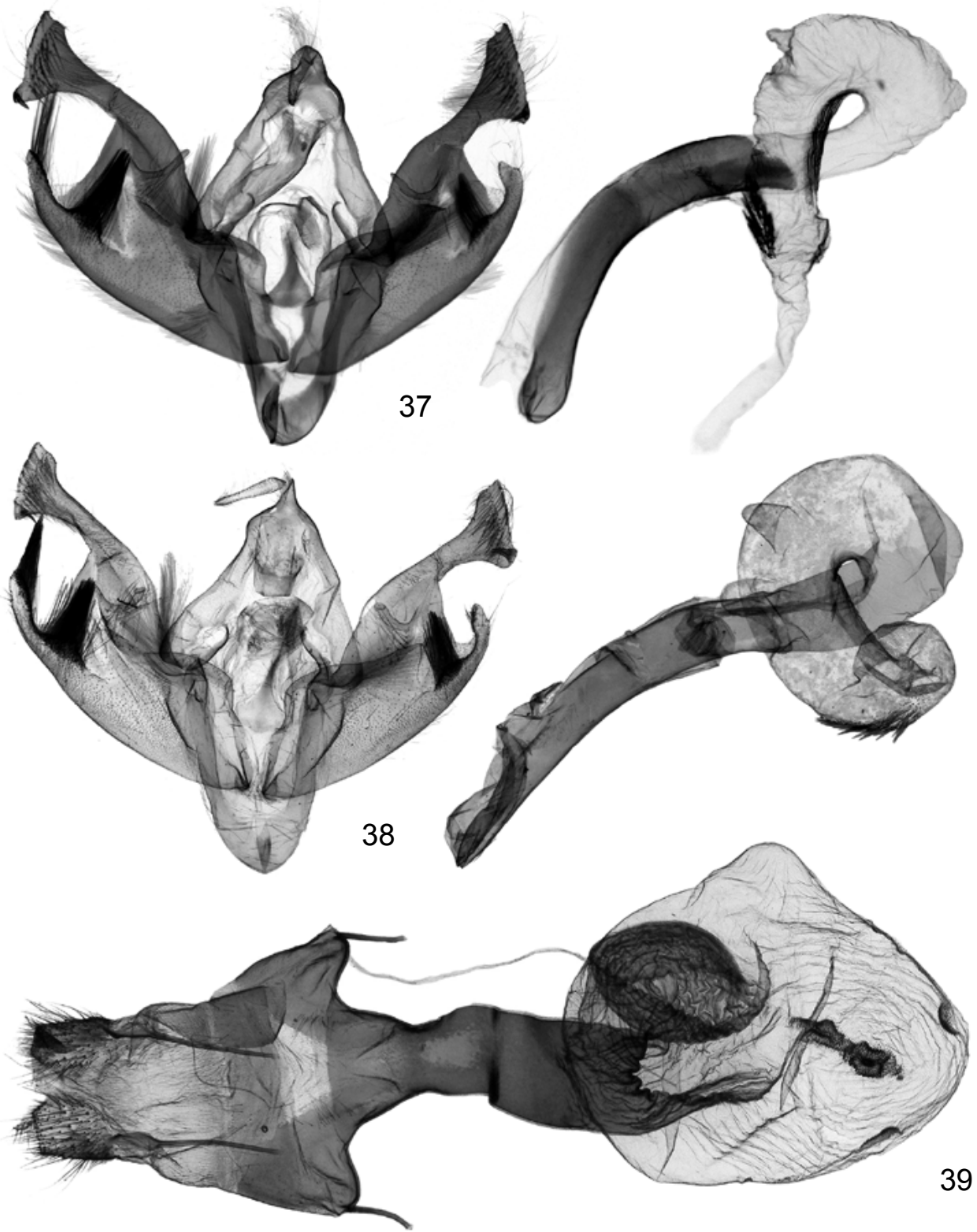

Figs 37-39. Genitalia figures of Polia lama anthracosparsa ssp. n.: 37 = male, paratype, Pakistan, Himalaya Mts, RL8730, 38 = male, Paratype, Pakistan, Himalaya Mts, VZ8752, 39 = female, paratype, Pakistan, Himalaya Mts, RL12348 


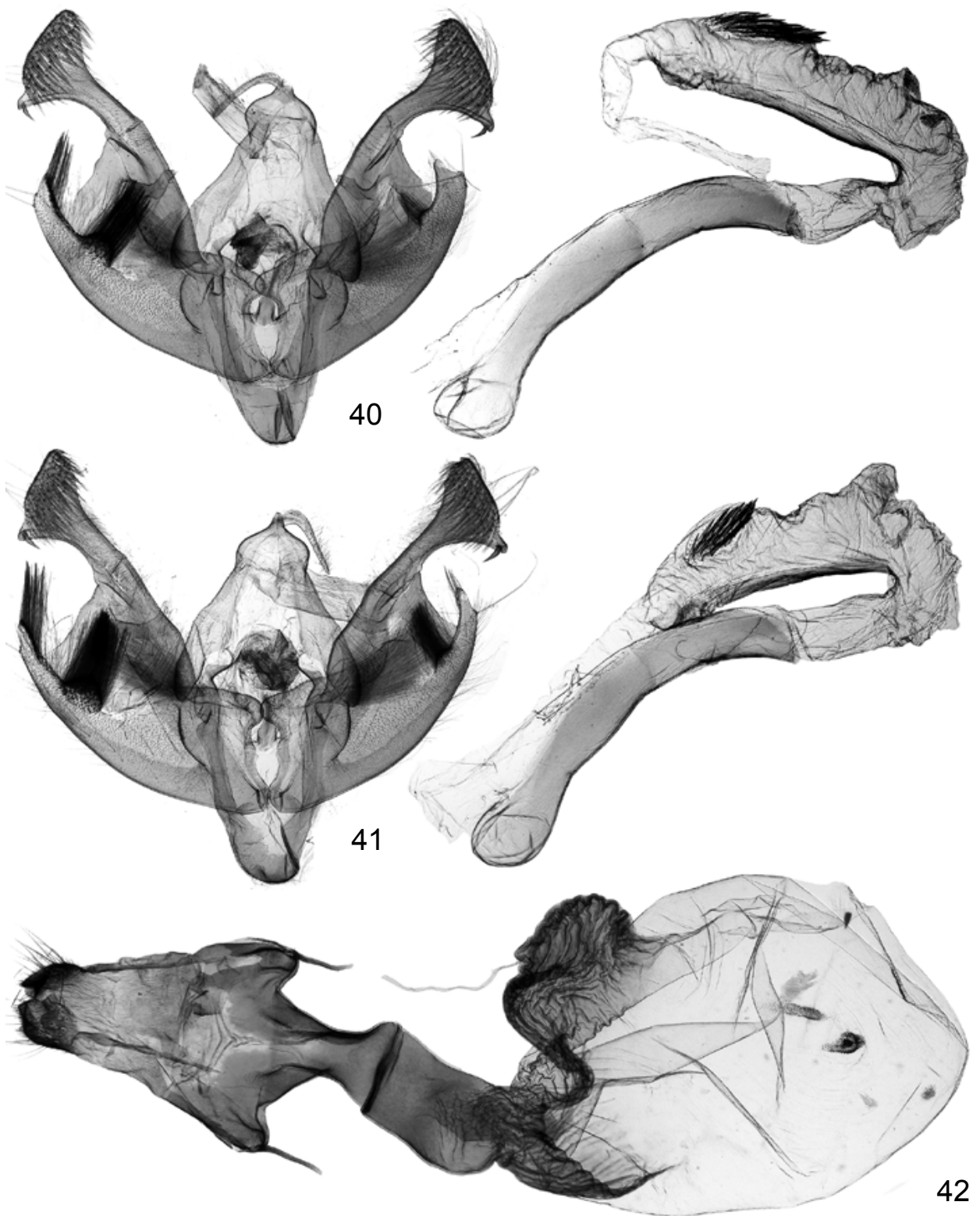

Figs 40-42. Genitalia figures of Polia goliath (Oberthür, 1880): $40=$ male, North Korea, RL11031, 41 = male, Taiwan, RL11030, 42 = female, Russian Far East, RL12346 
male $50-54 \mathrm{~mm}$ ), broader and less acutely pointed forewings, generally darker colouration, often with dilute markings, densely covered by blackish scales.

In the male genitalia (Figs 37-38), the neck of cucullus is relatively short and the head relatively broad triangular, not acute basally as in the typical subspecies. One of the diverticula of vesica is less prominent than in the other subspecies.

In the female genitalia (Fig. 39), the appendix bursae is globular while this part of the bursae in other subspecies is rather dome-shaped or obtuse.

Description. Relatively large moths (wingspan: male $43-48 \mathrm{~mm}$, female $50-54 \mathrm{~mm}$ ) with strong body, elongate forewings with acute apex, dark fuscous-grey ground colour covered densely by blackish brown scales; noctuid pattern regular. Hindwings basally light brownish-grey with darker brownish-grey terminal band. Dorsal crest more prominent than in the other subspecies, consisting of blackish-brown tufts on the first abdominal segments. Sexes similar.

Male genitalia (Figs 37-38). Genital capsule strongly asymmetrical, right saccular process short, obtuse terminally, left saccular process with two prominent tufts of strong setae. Cucullus relatively large, not acute basally. Aedeagus moderately sclerotised, slender; vesica with one prominent and one less expressed diverticula medially and with a long fascia of cornuti terminally.

Female genitalia (Fig. 39). Antrum and ductus bursae very strongly sclerotised, antrum triangular, ductus bursae relatively long, rugulose distally, appendix bursae rather globular-discoidal, corpus bursae with one large double signum and two smaller signa.

Acknowledgements - The authors are grateful to Péter Gyulai (Miskolc, Hungary), Sabine Gaal-Haszler, Martin Lödl (Naturhistorisches Museum, Vienna), Axel Hausmann, Ulf Buchsbaum (Zoologische Staatssammlung Munich), Martin Honey, Alberto Zilli (The Natural History Museum, London), Wolfram Mey (Museum für Naturkunde, Berlin), Robert Trusch, Michael Falkenberg (Landessammlungen für Naturkunde, Karlsruhe) for the possibility of study valuable collection materials, including types; to Peter Huemer for important information on molecular relationships, and to Csenkey Lórántné (Hungarian Natural History Museum) and Péter Kozma (University of Debrecen) for technical assistance.

Surveys were financially supported by the K116694 grant (Z. Varga) of the National Foundation of Research, Development and Innovation (NKFI-OTKA) and by the SYNTHESYS Project, financed by European Community Research Infrastructure Action under the FP6 „Structuring the European Research Area" Programme: Grants DE-TAF-6708 (Z. Varga); GB-TAF-2644, DE-TAF-3514 and AT-TAF-5609 (G. Ronkay); GB-TAF-2656 (L. Ronkay).

\section{REFERENCES}

Heydemann, F. (1944): Zur Kenntnis der Gattung Aplecta Guen. und zweiter „Dual Species" in derselben (Lep. Noct.). - Entomologische Zeitung. Entomologischen Vereine zu Stettin 105: 12-33. 
McCabe, T.M. (1980): A reclassification of the Polia complex for North America (Lepidoptera: Noctuidae). - New York State Museum, Bulletin No. 432. i-vi, 1-141 pp.

VARGA, Z. \& RonKAY, L. (2013): Structural constraints of secondary asymmetry in male external genitalia of Noctuidae. - Insect Systematics \& Evolution 44: 349-372. https://doi .org/10.1163/1876312X-04402001

VARGA, Z., RonkAY, G. \& RonkAY, L. (2018): Metallopolia, a new subgenus of Polia (Noctuidae, Noctuinae, Hadenini), with the description of two new species and a new subspecies. - Journal of Asia-Pacific Entomology 21: 217-232. https://doi.org/10.1016/j.aspen .2017.12.005

VArga, Z., Ronkay, G. \& Ronkay, L. (2017b): Revised taxonomic check list of the Eurasiatic species of the subtribe Poliina (Noctuidae, Noctuinae, Hadenini). - Deutsche Entomologische Zeitschrift 64(2): 133-160. https://doi.org/10.3897/dez.64.21455

Zahiri, R., Lafontaine, J. D., Schmidt, B. C., DeWaArd, J. R., Zakharov, E. V. \& Hebert, P. D. N. (2014): A transcontinental challenge - A test of DNA barcode performance for 1,541 species of Canadian Noctuoidea (Lepidoptera). - PLoS ONE 9(3): e92797. https://doi.org/10.1371/journal.pone.0092797

Received June 5, 2018, accepted September 18, 2018, published May 31, 2019 